\title{
Effects of processing on physical properties of extruded snacks with blends of sour cassava starch and flaxseed flour
}

\author{
Camila de Barros MESQUITA ${ }^{1}$, Magali LEONEL ${ }^{1 \star}$, Martha Maria MISCHAN ${ }^{2}$
}

\begin{abstract}
The opportunity to supplement common cassava biscuits with a product of higher nutritional value meets consumer expectations. In this work it was studied the effects of process parameters and flaxseed addition on physical properties of expanded snacks. Extrusion process was carried out using a single screw extruder in a factorial central composite rotatable design with four factors: flaxseed flour percentage (0-20\%), moisture (12-20\%), extrusion temperature $\left(90-130{ }^{\circ} \mathrm{C}\right)$ and screw speed (190-270). The effect of extrusion variables was investigated in terms of expansion index, specific volume, water absorption index, water solubility index, color parameters $\left(\mathrm{L}^{*}, \mathrm{a}^{*}, \mathrm{~b}^{*}\right)$ and hardness. The data analysis showed that variable parameters of the extrusion process and flaxseed flour affected physical properties of puffed snacks. Among the experimental conditions used in the present study, expanded snack products with good physical properties can be obtained under the conditions of $10 \%$ flaxseed flour, 230 rpm screw speed, temperature of $90^{\circ} \mathrm{C}$ and moisture of $12 \%$.
\end{abstract}

Keywords: extrusion; physical properties; starch; Linum usitatissimum L.

\section{Introduction}

Extrusion cooking is an important processing technique in the food industry as it is considered to be an efficient manufacturing process. Extrusion combines a number of unit operations i.e. mixing, cooking, shearing, puffing, final shaping and drying in one energy efficient rapid continuous process and can be used to produce a wide variety of starchy foods including snacks, ready to eat (RTE) cereals, confectioneries and extruded crisp breads (HARPER, 1989; SUKNARK; PHILLIPS; CHINNAN, 1997). This process of high temperature short time extrusion bring gelatinization of starch, denaturation of protein, modification of lipid and inactivation of enzymes, microbes and many antinutritional factors (BHATTACHARYA; PRAKASH, 1994).

The extrusion of starchy foods results in gelatinization, partial or complete destruction of the crystalline structure and molecular fragmentation of starch polymers. During extrusion, protein structures are disrupted and altered under high shear, pressure, and temperature. Protein solubility decreases and cross-linking reactions occur possibly due to some covalent bonds formed at high temperature, as well as protein denaturation and formation of complexes between starch and lipids and between protein and lipids (COLONNA; MERCIER, 1983; PÉREZ et al., 2008).

Consumer acceptance of extruded foods is mainly due to the convenience, value, attractive appearance and texture found to be particular for these foods, especially when it concerns snack products (ANTON et al., 2008). Extruded foods have been proven to provide nutritious products and combine quality ingredients and nutrients to produce processed foods that contain precise levels of each required nutrient (CHEFTEL, 1986; YAGCI; GÖGÜS, 2008).

Brazil is the third largest producer of cassava (233.795.973 tons), which is grown in all regions and represents the second most important source of starch in Brazil, constituting an industrial input into strategic sectors of the economy. In 2010, the country produced 26.6 million tons of cassava roots within an area of 1.77 million ha, and the main producers were the states of Pará, Paraná, Bahia, Maranhão and Rio Grande do Sul. In the same year, the production of cassava starch yielded 542.2 thousand tons, and the Paraná State was the greatest producer (LEONEL; FREITAS; MISCHAN, 2009; INSTITUTO..., 2011).

The sour starch is a modified product of cassava produced by natural fermentation of starch and drying in the sun. This modified starch is widely used in food products due to the property of natural expansion.

The opportunity to supplement common cassava sour biscuits with a product of higher nutritional value is inherently beneficial to the public interests.

Seeds are the major form of dispersal of plants in the environment and are nowadays the subject of intense studies because of their use as major food sources. Among the various seeds of interest, flaxseed presents a nutritional and pharmacological value as a source of biologically active phytochemicals such as linolenic acid and lignans and is thus widely used as a dietary supplement (ATTOUMBRÉ et al., 2011). The flaxseed (Linum usitatissimum L.) contains approximately

\footnotetext{
Received 27/4/2012

Accepted 23/7/2013

${ }^{1}$ Centro de Raízes e Amidos Tropicais - CERAT, Universidade Estadual Paulista - UNESP, Rua Doutor José Barbosa de Barros, 1780, Jardim Paraíso, CEP 18610-307,

Botucatu, SP, Brasil,e-mail:mleonel@cerat.unesp.br

${ }^{2}$ Instituto de Biociências, Universidade Estadual Paulista - UNESP, Botucatu, SP, Brasil

${ }^{*}$ Corresponding author
} 
$40 \%$ oil, $30 \%$ dietary fiber, $20 \%$ protein, $6 \%$ moisture and $4 \%$ ash (OOMAH; MAZZA, 1998).

Several reports have attempted to relate extrusion parameters to chemical and physical properties of extrudates such as raw material composition, feed moisture, screw speed, extrusion temperature and feed rate (HAGENIMANA; DING; FANG, 2006; YULIANI et al., 2006). In this study it was investigated the effects of screw speed, extrusion temperature, moisture and percentage of flaxseed flour in the mixture with sour cassava starch on physical properties of puffed snacks.

\section{Materials and methods}

The employed raw materials were industrial sour cassava starch (Ourominas, São Pedro do Turvo, São Paulo, Brazil) and flaxseed flour acquired in local market (Jasmine, Brazil).

The chemical composition of flaxseed flour was: $6.8 \%$ moisture, $22.06 \%$ protein, $40.79 \%$ lipids, $3.11 \%$ ash, $12.04 \%$ fiber and $15.2 \%$ total carbohydrate.

Mixtures of sour cassava starch and flaxseed flour were prepared and after homogenization in a homogenizer in " $Y$ " TE201/5 (Tecnal, Brazil) for 5 minutes, 28 samples of $1 \mathrm{~kg}$ were separated for moisture conditioning.

Extrusion was carried out using a complete line of INBRA RX (Inbramaq, Brazil), which has a motor coupled with a speed reducer (extrusion by mechanical friction), besides a single extrusion screw, with $130 \mathrm{~mm}$ of barrel diameter, $440 \mathrm{~mm}$ of extruder length, a hydraulic cooling system for temperature control, variable speed, and $50 \mathrm{~kg} \mathrm{~h}^{-1}$ capacity.

The Response Surface Methodology (RSM) is a widely adopted tool for the quality of optimization process. The RSM, originally described by Box and Wilson (1951), is effective for responses that affect many factors and their interactions. The central composite rotatable composite design (CCRD) was adopted to predict responses based on few sets of experimental data in which all factors were varied within a chosen range. A four factors and five level experimental design was adopted for this work (BOX; HUNTER, 1957) (Table 1).

The extrusion process parameters were:

- Constant parameters: extrusion temperature in the $1^{\text {st }}$ (20 to $25^{\circ} \mathrm{C}$ ) and $2^{\text {nd }}$ zones $\left(40\right.$ to $\left.45^{\circ} \mathrm{C}\right)$; screw compression ratio (3:1); screw diameter (19 $\mathrm{mm})$, die diameter ( $4 \mathrm{~mm})$; feed rate $\left(150 \mathrm{~g} \mathrm{~min}^{-1}\right)$; and cutting speed $(90 \mathrm{rpm})$.

- Variable parameters: flaxseed flour percentage, feed moisture; barrel temperature in the $3^{\text {rd }}$ zone; and screw speed (Table 1). The variation ranges between the upper and the lower limit of variables were set based on preliminary tests.

During the extrusion process a portion of the next test material was used to purge the extruder. It was collected $500 \mathrm{~g}$ of extruded sample after achieving steady-state flow in the extruder. The extruded samples were dried $\left(40^{\circ} \mathrm{C}\right)$ to the desired moisture (6-7\%) in an air circulation oven MA037 (Marconi, Brazil). Each dried sample was divided into two portions and kept in plastics bags hermetically sealed until evaluation.

The expansion index (EI) was evaluated after extrusion and before drying. It was determined with a digital caliper. Expansion indexes are derived from the division of radial expansion by the die orifice diameter $(4.0 \mathrm{~mm})$ (FAUBION; HOSENEY, 1982). The considered value was obtained by the arithmetic mean of measurements of 20 different expanded products in each treatment.

Specific volume (SV) was determined according to the mass displacement method (millet seed) using a graded pipette (FAUBION; HOSENEY, 1982).

Water absorption index (WAI) and water solubility index (WSI) were assessed before and after extrusion process (ANDERSON et al., 1969). The extrudates were ground to a mean particle size of approximately $150 \mu \mathrm{m}$. A $2.5 \mathrm{~g}$ sample was dispersed in $25 \mathrm{~g}$ distilled water, using a glass rod to break up any lumps. After stirring for 30 minutes, the dispersions were rinsed into tared centrifuge tubes, made up to $32.5 \mathrm{~g}$ and centrifuged at $5000 \mathrm{rpm}$ for 10 minutes. The water absorption index (WAI) is the weight of gel obtained per gram of dry ground sample. The water solubility index (WSI) is the percentage of dry matter recovered after the supernatant is evaporated from the water absorption determination. WAI and WSI were calculated as:

WAI $=\frac{\text { Weight of Sediment }}{\text { Weight of Dry Solids }}$

WSI $=\frac{\text { Weight of Dissolved Solids in Supernatant } \times 100}{\text { Weight of Dry Solids }}$

Color measurements (CIE L $\mathrm{L}^{*}, \mathrm{a}^{*}, \mathrm{~b}^{*}$ color space) were performed on raw materials before extrusion and on ground extruded samples using a Minolta CR-400 model colorimeter (Konica Minolta, Ramsey, NJ, USA). The color of extrudates was expressed as the average of three $L^{*}, a^{*}$, and $b^{*}$ readings, where $L^{\star}$ stands for brightness, $+a^{\star}$ redness, $-a^{\star}$ greenness, $+b^{\star}$ yellowness, and $-\mathrm{b}^{\star}$ blueness. A white calibration plate was used to standardize the equipment prior to color measurements.

Table 1. Levels of variation and variable parameters of the extrusion process.

\begin{tabular}{|c|c|c|c|c|c|}
\hline \multirow[t]{2}{*}{ Independent variables } & \multicolumn{5}{|c|}{ Levels of variation } \\
\hline & $-<$ alpha $>$ & -1 & 0 & +1 & $+<$ alpha $>$ \\
\hline Flaxseed flour & 0 & 5 & 10 & 15 & 20 \\
\hline Screw speed (rpm) & 190 & 210 & 230 & 250 & 270 \\
\hline Extrusion temperature $\left({ }^{\circ} \mathrm{C}\right)$ & 50 & 70 & 90 & 110 & 130 \\
\hline Moisture content (\%) & 12 & 14 & 16 & 18 & 20 \\
\hline
\end{tabular}

$<$ alpha $>=2$. 
The hardness of samples was determined using a texture analyzer TA-XT2 (Stable Micro Systems, Surrey, England) with a $50 \mathrm{~kg}$ load cell and a probe HDP/WBV (Warner Bratzler set with "V" slot blade for USDA Standard). The test speed was $1 \mathrm{~mm} / \mathrm{s}$. For each treatment ten extrudates were assayed.

Response Surface Methodology describes the behavior of a system in which the independent variables $\left(\mathrm{X}_{\mathrm{k}}\right)$ and the dependent variable or response $\left(\mathrm{Y}_{\mathrm{i}}\right)$ are combined. The response is a function of the levels at which those factors were combined and defined.

The model was fitted by the option "step-wise" of SAS program; the obtained model was evaluated through F-test using as denominator the pure error mean square.

The stepwise method is a modification of the forwardselection technique and differs in that variables already in the model do not necessarily stay there. As in the forward-selection method, variables are added one by one to the model, and the $F$ statistic for a variable to be added must be significant at the SLENTRY= level. After a variable is added, however, the stepwise method looks at all the variables already included in the model and deletes any variable that does not produce an $F$ statistic significant at the SLSTAY= level. Only after this check is made and the necessary deletions are accomplished another variable can be added to the model. The stepwise process ends when none of the variables outside the model has an $F$ statistic significant at the SLENTRY= level and every variable in the model is significant at the SLSTAY= level, or when the variable to be added to the model is the one just deleted from it.

\section{Results and discussion}

The degree of expansion of extruded product is closely related to the size, number and distribution of air cells surrounded by the cooked material. The expansion occurring in a food material depends on the pressure differential between the die and atmosphere. The high pressure close to the discharge of the die is reduced when the products leaves the extruder, causing flash evaporation of water and expansion of the product. As the conditions used in the processing of sour cassava starch and flaxseed flour mixtures, the expansion index ranged from 2.23 to 5.36. It was not observed effect of independent variables on this expansion parameter (Table 2).

The specific volume (SV) of extruded products ranged from $1.43 \mathrm{~mL} . \mathrm{g}^{-1}$ to $17.24 \mathrm{~mL} . \mathrm{g}^{-1}$ with the higher value observed under low moisture (12\% and $24 \%), 10 \%$ flaxseed flour, temperature of $130{ }^{\circ} \mathrm{C}$ and $230 \mathrm{rpm}$ of the screw speed. Specific volume is a main performance index for extrusion puffed food. It is a measure of volumetric expansion, which is the sum of radial and axial expansions.

In Brazil, sour cassava starch biscuits, produced by mixing of sour cassava starch with hot water $\left(100^{\circ} \mathrm{C}\right)$, oil and salt and then molded and baked, are classified to the specific volume as: low SV $\left(<5.0 \mathrm{ml} . \mathrm{g}^{-1}\right)$, medium $\left(5.0\right.$ to $\left.10.0 \mathrm{ml.g}{ }^{-1}\right)$, and large (>10.0 ml. $\mathrm{g}^{-1}$ ) (CAMARGO; LEONEL; MISCHAN, 2008). Based on this classification, the extruded products fit into all levels of specific volume.

Temperature showed a highly significant linear effect on the specific volume of extrudates. Moisture showed positive squared

Table 2. Regression equation coefficients of fitted models.

\begin{tabular}{|c|c|c|c|c|c|c|c|c|}
\hline & EI & SV & WSI & WAI & $\mathrm{L}^{*}$ & $a^{*}$ & $b^{*}$ & $\mathrm{H}$ \\
\hline Intercept & 3.64 & 5.77 & 52.32 & 13.76 & 66.4 & 5.87 & 16.37 & 1.31 \\
\hline $\mathrm{FF}$ & ns & ns & ns & $-1.12^{\star}$ & $-4.0^{\star * *}$ & $0.62^{\star *}$ & ns & ns \\
\hline SS & ns & ns & ns & ns & ns & ns & $0.66^{* *}$ & ns \\
\hline $\mathrm{T}$ & ns & $3.18^{\star * *}$ & $23.5^{\star * *}$ & ns & $1.74^{\star}$ & ns & $1.12^{\star * *}$ & ns \\
\hline M & ns & ns & ns & ns & ns & ns & $-0.73^{* * *}$ & ns \\
\hline $\mathrm{FF}^{\star} \mathrm{FF}$ & ns & ns & $-7.58^{*}$ & ns & ns & ns & $-0.74^{\star * *}$ & $1.27^{\star \star \star}$ \\
\hline $\mathrm{SS}^{\star} \mathrm{SS}$ & $0.3^{*}$ & ns & ns & ns & ns & ns & $0.67^{\star * *}$ & ns \\
\hline $\mathrm{T}^{\star} \mathrm{T}$ & ns & ns & ns & ns & ns & ns & $-0.52^{\star *}$ & ns \\
\hline $\mathrm{M}^{\star} \mathrm{M}$ & ns & $1.28^{*}$ & ns & ns & ns & ns & ns & ns \\
\hline $\mathrm{FF}^{\star} \mathrm{SS}$ & ns & ns & ns & ns & ns & ns & ns & ns \\
\hline $\mathrm{FF}^{\star} \mathrm{T}$ & ns & ns & ns & ns & ns & ns & ns & ns \\
\hline $\mathrm{FS}^{\star} \mathrm{M}$ & ns & ns & ns & ns & ns & ns & $0.43^{*}$ & ns \\
\hline $\mathrm{SS}^{\star} \mathrm{T}$ & ns & ns & ns & ns & ns & ns & $0.85^{\star *}$ & ns \\
\hline $\mathrm{SS}^{\star} \mathrm{M}$ & ns & ns & ns & ns & ns & ns & ns & ns \\
\hline $\mathrm{T}^{\star} \mathrm{M}$ & ns & ns & ns & ns & ns & ns & $-0.55^{\star *}$ & ns \\
\hline $\mathrm{R}^{2}$ & 0.38 & 0.57 & 0.73 & 0.17 & 0.58 & 0.33 & 0.90 & 0.67 \\
\hline F value & 4.12 & 17.24 & 34.51 & 5.65 & 17.99 & 13.15 & 19.20 & 54.43 \\
\hline F tab. & 4.21 & 3.37 & 3.37 & 4,21 & 3.37 & 4.21 & 2.37 & 4.21 \\
\hline $\operatorname{Pr}>F$ & 0.52 & $<0.0001$ & $<0.0001$ & 0.0248 & $<0.0001$ & 0.0012 & $<0.0001$ & $<0.0001$ \\
\hline Lack of fit & 0.02 & 0.05 & 0.09 & 0.02 & 0.17 & 0.01 & 0.20 & 0.04 \\
\hline
\end{tabular}

$\mathrm{FF}=$ flaxseed flour; $\mathrm{SS}=$ screw speed; $\mathrm{T}=$ temperature; $\mathrm{M}=$ moisture; $\mathrm{ns}=$ non-significant; ${ }^{*}=\mathrm{P}<0.05,{ }^{* *}=\mathrm{P}<0.01,{ }^{* * *}=\mathrm{P}<0.001 ; \mathrm{EI}=\mathrm{expansion}$ index; $\mathrm{SV}=$ specific volume; WSI $=$ water solubility index; WAI $=$ water absorption index; $\mathrm{L}^{*}=$ brightness $\mathrm{a}^{*}=$ redness or greenness; $\mathrm{b}^{*}=$ yellowness or blueness; $\mathrm{H}=\mathrm{Hardness.}$ 
effect on SV (Table 2). The model proposed was significant but it was not a predictor model.

An increase in specific volume is observed at high extrusion temperature and opposite extremes conditions of moisture in mixtures (Figure 1). In conditions of low moisture content of mixtures it was possible to obtain high specific volume and expansion index.

Higher values of specific volume (SV) under high moisture condition can be associated with the levels of non-starch components of flaxseed flour.

The fiber component has the capacity to hydrate itself and, consequently, to compete for water and restrict availability of this plasticizer thereby impairing the gelatinization process (YANNIOTIS; PETRAKI; SOUMPASSI, 2007).

Camargo, Leonel and Mischan (2008), evaluating the physical properties of extruded biscuits of sour cassava starch with fibers, observed that the values of specific volume ranged from $1.5 \mathrm{~mL} . \mathrm{g}^{-1}$ to $5.6 \mathrm{~mL} . \mathrm{g}^{-1}$ with a significant effect of moisture and fiber percentage. In conditions of $7.5 \%$ fiber and $20 \%$ moisture was obtained the higher SV.

Foods with lower moisture tend to be more viscous than those with higher moisture, therefore, the pressure differential would be smaller for higher moisture foods, leading to a less expanded product (SINGH; SEKHON; SING, 2007).

Trevisan and Arêas (2012), developed corn and flaxseed snacks with high fiber content using response surface methodology, concluded that the characteristic composition of the raw material used may explain the higher moisture content (19\%) observed for the maximum expansion of corn-flaxseed snack versus values for corn starch alone.

The changes in extrudates properties by moisture and temperature variations may be attributed to variation in starch degradation. At very high temperature and lower moisture the vaporization occurs in a violent way and may cause breakage of the structure, hampering expansion. Low moisture content in

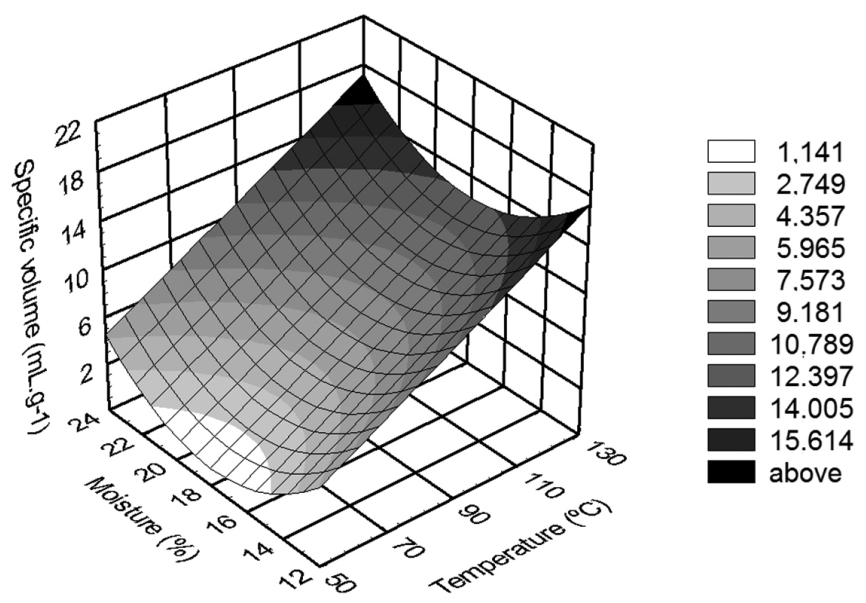

Figure 1. Effects of extrusion parameters on specific volume of extruded products with the screw speed and percentage of flaxseed flour in central point (230 rpm and 10\% respectively). the material may restrain its flow inside the extruder, increasing shear and residence time (HASHIMOTO; GROSSMANN, 2003).

Color is an important characteristic of extruded foods. Color changes can provide information about the extent of browning reactions such as caramelization, Maillard reaction, degree of cooking and pigment degradation that take place during the extrusion process (ALTAN; McCATHY; MASKAN, 2008).

The color analysis of the raw materials before extrusion showed brightness of $94.71, \mathrm{a}^{*}$ of 1.09 and $\mathrm{b}^{*}$ of 5.87 for the sour cassava starch. The flaxseed flour had $\mathrm{L}^{\star}$ of $44.11,8.74$ of $a^{\star}$ and $b^{\star}$ of 15.17 .

The results obtained for the brightness $\left(\mathrm{L}^{*}\right)$ of extrudates ranged from 55.13 to 80.54 . The statistical analysis showed negative linear effect of the percentage of flaxseed flour and positive linear effect of extrusion temperature on the brightness (Table 2). The fitted model can be considerably predictive (Lack of fit $p=0.1781$ ). Yagci and Gögüs (2008) reported that with significant probability values $(\mathrm{p}<0.001)$ and non-significant lack of fit, the models could be adequately used as predictor models, regardless of low coefficient of determinations.

Under conditions of low percentage of flaxseed flour and high extrusion temperature the $\mathrm{L}^{*}$ of products was higher (Figure 2).

Similar results for the effect of temperature were cited by Leonel, Freitas and Mischan (2009) who observed that under high moisture and high barrel temperature conditions, there was less darkening of the extruded cassava starch, i.e. greater $L^{*}$.

The results obtained for the $\mathrm{a}^{*}$ value of the extruded products ranged from 2.8 to 6.87. Analysis of the regression coefficients showed a positive linear effect of temperature on this component of chromaticity (Table 2).

Responses of the $\mathrm{b}^{*}$ color parameter, which represents variation from blue to yellow, varied according to the treatment

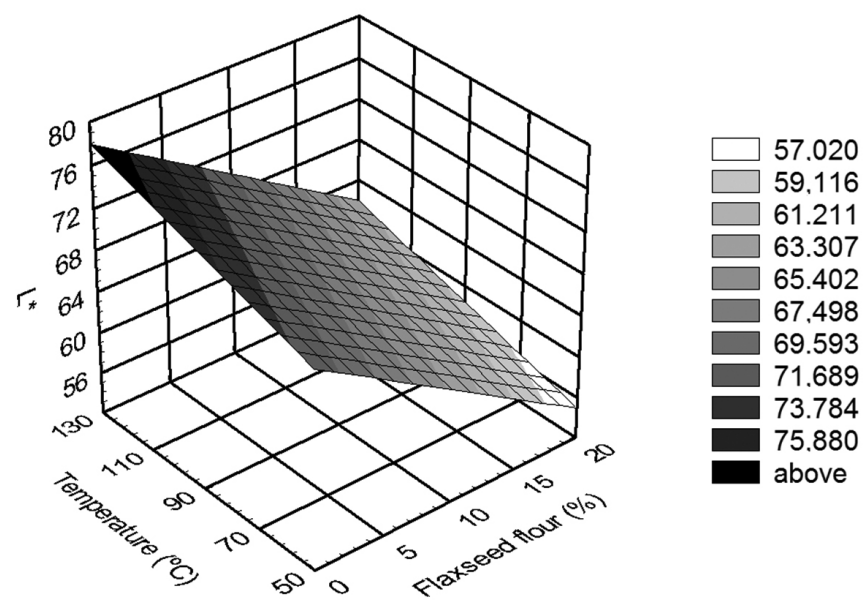

Figure 2. Effect of extrusion temperature and percentage of flaxseed flour on $\mathrm{L}^{\star}$ of extruded products with moisture and screw speed in central point (18\% and $230 \mathrm{rpm}$ respectively). 
(from 13.26 to 20.93). Regression analysis indicated effects of all variable parameters on this chromaticity component (Table 2). The model can be used as a predictor model. It was significant, well-fitted $\left(\mathrm{R}^{2}=0.90\right)$, and the lack of fit was not significant $(p=0.2034)$.

Under conditions of high temperature and low moisture or high temperature and high screw speed, $b^{*}$ values were higher. Under high moisture and low flaxseed flour percentage $b^{\star}$ values were lower (Figure 3).

Processing conditions of high temperature and low moisture are recognized to favor the reaction between reducing sugars and amino acids that results in the formation of colored compounds and in the reduction of the lysine amino acid. If browning is too intense, colors and undesirable tastes may arise.

The water absorption index (WAI) measures the volume occupied by the starch after swelling in excess water, and indicates the integrity of starch in aqueous dispersion. Water solubility index (WSI), often used as an indicator of degradation of molecular components, measures the degree of starch conversion during extrusion which is the amount of soluble
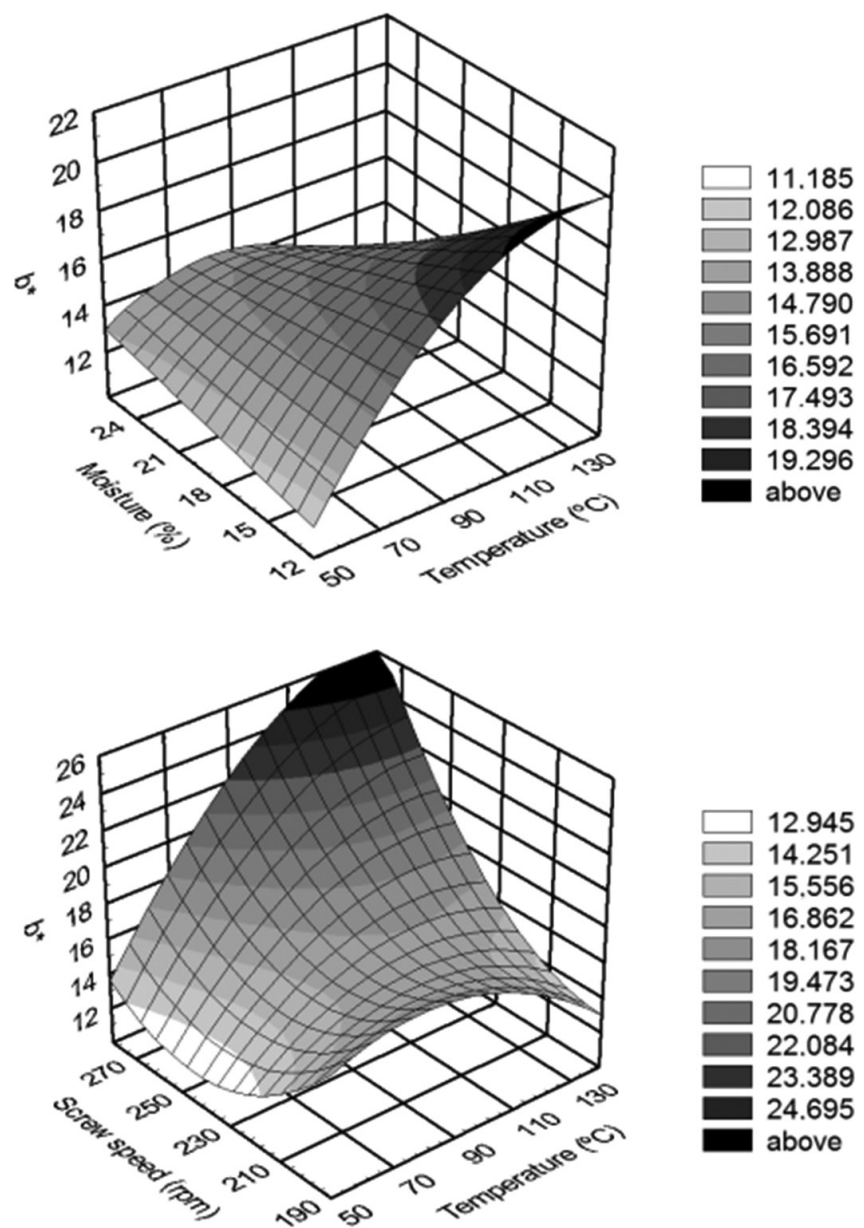

Figure 3. Effects of moisture, temperature and screw speed on $b^{\star}$ of extruded products with percentage of flaxseed flour in central point (10\%). polysaccharide released from the starch component after extrusion (YANG et al., 2008).

The extruded products presented improvement in the solubility and water absorption. Before extrusion blends showed WSI ranging from 1.25 to $1.88 \%$ and WAI ranging from 2.22 to 2.28 g gel.g ${ }^{-1}$.

The WSI obtained in the different extrusion treatments ranged from 11.06 to $73.08 \%$. Under condition of high extrusion temperature and intermediate percentage of flaxseed flour WSI was higher (Figure 4).

Besides the starch gelatinization, which results in the release of amylose and amylopectin, can also occur dextrinization and other reactions that lead to the formation of low molecular weight compounds, influencing the WSI (CAMIRE; KRUMHAR, 1990).

Taverna, Leonel and Mischan (2012) evaluated the changes in physical properties of extruded sour cassava starch and quinoa flour blends snacks and observed higher levels of water solubility index in conditions of high amount of quinoa flour in the mixture and low screw speed, as well as, under conditions of high temperature and high amount of quinoa flour.

The WAI ranged from 8.37 to $19.44 \mathrm{~g} \mathrm{gel.g}^{-1}$ in the different extrusion conditions. It was observed a negative linear effect of flaxseed flour percentage on WAI, but it was not possible to obtain a predictive model for this parameter $\left(R^{2}=0.17\right.$, lack of fit $p=0.0186$ ).

Protein denaturation, starch gelatinization and swelling of the crude fiber, which occurred during extrusion, could all be responsible for the variation of WAI of extrudates.

Increase in the value of WAI may probably be caused by uncovering of hydrophilic groups in extruded starch-protein material, by unfolding and loosening of biopolymer chains, greater availability and easier penetration of structures by water molecules (MARZEC; LEWICKI, 2006).

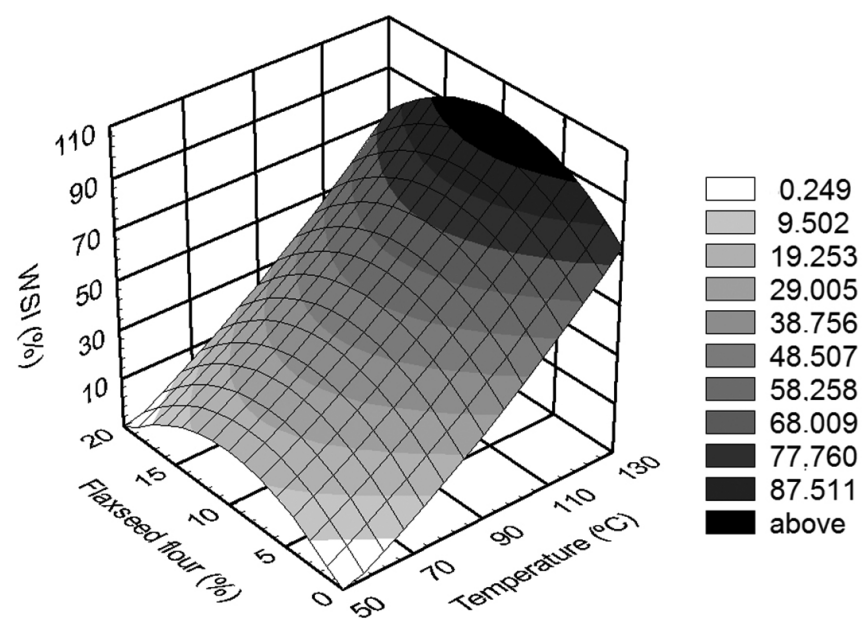

Figure 4. Effects of extrusion parameters on water solubility index of extruded products. 




Figure 5. Effect of flaxseed flour percentage in the mixture on hardness of extruded products.

The textural property of samples was determined by measuring the strength required to break the extrudate. The hardness of the extruded products ranged from 0.83 to $6.86 \mathrm{kgf}$. There was a positive quadratic effect of flaxseed flour on hardness (Figure 5). The model was significant but it cannot be used as a predictor model due the low coefficient of determination $\left(\mathrm{R}^{2}=0.67\right)$ and significant lack of fit.

The texture of extruded product depends mainly on the processing parameters, but chemical composition of the ingredients is also important (STANLEY, 1986). The high content of protein and lipids in flaxseed might have affected characteristics of the starch matrix (i.e., the viscoelastic properties of molten extrudate) so that it no longer holds water vapor, resulting in higher break strength.

Leonel, Martins and Mischan (2010) observed the influence of soya flour mixed with sour cassava starch and extrusion temperature on hardness of snacks. In conditions of low soya flour and high temperature the snacks hardness decreased.

Lipid complexation with starch is a very important reaction in extrusion cooking that affects structure formation and texture of the extruded products (DE PILLI et al., 2011).

Addition of fatty acids alters the physical and chemical properties of starchy foods (SINGH et al., 1998). The changes produced in starchy foods have been attributed to the formation of complexes between amylose and lipids. Lipids have been reported to form inclusion compounds with amylose, with the hydrocarbon portion of the lipid located within the helical cavity of amylose (KAUR; SINGH, 2000).

\section{Conclusion}

This study evidenced the effects of the extrusion process variables and flaxseed flour on the characteristics of a flaxseedsour cassava starch-based snack. Temperature affected specific volume, water solubility index and color parameters $\left(\mathrm{L}^{*}\right.$ and $\left.\mathrm{b}^{*}\right)$. Percentage of flaxseed flour in the mixture had effect on $\mathrm{L}^{*}$. Moisture influenced specific volume and $\mathrm{b}^{*}$ and screw speed had effect on $b^{*}$ value. In puffed snacks is desirable high SV, high $L^{*}$, low WSI and low hardness. Under conditions of low amount of flaxseed flour $(10 \%)$, low moisture $(12 \%), 90{ }^{\circ} \mathrm{C}$ of the extrusion temperature and $230 \mathrm{rpm}$ of the screw speed can be obtained products with desirable physical characteristics for puffed snacks.

\section{Acknowledgements}

The authors acknowledge the financial support of CNPq and FAPESP, Brazil.

\section{References}

ANDERSON, R. A. et al. Gelatinization of corn grits by roll and extrusion cooking. Cereal Science Today, v. 14, n. 1, p. 4-11, 1969. http://dx.doi.org/10.1002/star.19700220408

ANTON, A. A. et al. Influence of added bean flour (Phaseolus vulgaris L.) on some physical and nutritional properties of wheat flour tortillas. Food Chemistry, v. 109, n. 1, p. 33-41, 2008. http://dx.doi. org/10.1016/j.foodchem.2007.12.005

ALTAN, A.; McCATHY, K. L.; MASKAN, M. Twin-screw extrusion of barley-grape pomace belnds: extrudate characteristics and determination of optimum processing conditions. Journal of Food Engineering, v. 89, n. 1, p. 24-32, 2008. http://dx.doi.org/10.1016/j. jfoodeng.2008.03.025

ATTOUMBRÉ, J. et al. Investigation of lignan accumulation in developing Linum usitatissimum seeds by immunolocalization and HPLC. Phytochemistry Letters, v. 4, n. 2, p. 194-198, 2011. http:// dx.doi.org/10.1016/j.phytol.2011.03.004

BHATTACHARYA, S.; PRAKASH, M. Extrusion of blends of rice and chick pea flours: A response surface analysis. Journal of Food Engineering, v. 21, n. 3, p. 315-330, 1994. http://dx.doi. org/10.1016/0260-8774(94)90076-0

BOX, G. E. P.; WILSON, K. G. On the experimental attainment of optimum conditions. Journal of the Royal Statistical Society, v. 13, p. 1-45, 1951.

BOX, G. E. P.; HUNTER, J. S. Multifactor experimental design for exploring response surfaces. Annals of Mathematical Statistics, v. 28, p. 195-242, 1957. http://dx.doi.org/10.1214/aoms/1177707047

CAMARGO, K. F.; LEONEL, M.; MISCHAN, M. M. Produção de biscoitos extrusados de polvilho azedo com fibras: efeito de parâmetros operacionais sobre as propriedades físicas. Ciência e Tecnologia de Alimentos, v. 28, n. 3, p. 586-591, 2008. http://dx.doi. org/10.1590/S0101-20612008000300013

CAMIRE, M. E.; KRUMHAR, K. Chemical and nutritional changes in foods during extrusion. Critical Reviews in Food Science and Nutrition, v. 29, n. 1, p. 35-57, 1990. http://dx.doi. org/10.1080/10408399009527513

CHEFTEL, J. C. Nutritional effects of extrusion-cooking. Food Chemistry, v. 20, n. 4, p. 263-283, 1986. http://dx.doi. org/10.1016/0308-8146(86)90096-8

COLONNA, P.; MERCIER, C. Macromolecular modifications of manioc starch components by extrusion-cooking with and without lipids. Carbohydrate Polymers, v. 3, n. 2, p. 87-108, 1983. http:// dx.doi.org/10.1016/0144-8617(83)90001-2

DE PILLI, T. et al. Study of starch-lipid complexes in model system and real food produced using extrusing-cooking technology. Innovative Food Science and Emerging Technologies, v. 12, n. 4, p. 610616, 2011. http://dx.doi.org/10.1016/j.ifset.2011.07.011

FAUBION, J. M.; HOSENEY, R. C. High temperature and short time; extrusion-cooking of wheat starch and flour. I. Effect of moisture 
and flour type on extrudate properties. Cereal Chemistry, v. 59, n. 6, p. 529-533, 1982. Disponível em: <http://www.aaccnet.org/ cerealchemistry/backissues/1982/chem59_529.pdf $>$.

HAGENIMANA, A.; DING, X. L.; FANG, T. Evaluation of rice modified by extrudion cooking. Journal of Cereal Science, v. 43, n. 1, p. 3846, 2006. http://dx.doi.org/10.1016/j.jcs.2005.09.003

HARPER, J. M. Food extruders and their applications. In: MERCIER, C.; LINKO, P.; HARPER, J. M. (Ed.). Extrusion cooking. St. Paul: American Association of Cereal Chemists, 1989. p. 1-15.

HASHIMOTO, J. M.; GROSSMANN, M. V. E. Effects of extrusion conditions on quality of cassava bran/cassava starch extrudates. International Journal of Food Science and Technology, v. 38 , n. 5, p. 511-517, 2003. http://dx.doi.org/10.1046/j.13652621.2003.00700.x

INSTITUTO BRASILEIRO DE GEOGRAFIA E ESTATÍSTICA - IBGE. Disponível em: <http:// www.ibge.gov.br>. Acesso em: 06 dez. 2011.

KAUR, K.; SINGH, N. Amylose-lipid complex formation during cooking of rice flour. Food Chemistry, v. 71, n. 4, p. 511-517, 2000. http://dx.doi.org/10.1016/S0308-8146(00)00202-8

LEONEL, M.; FREITAS, T. S.; MISCHAN, M. M. Physical characteristics of extruded cassava starch. Scientia Agricola, v. 66, n. 4, p. 486-493, 2009. http://dx.doi.org/10.1590/S010390162009000400009

LEONEL, M.; MARTINS, J. C.; MISCHAN, M. M. Produção de snacks funcionais de polvilho azedo e farinha de soja. Ciência Rural, v. 40, n. 6, p. 1418-1423, 2010. http://dx.doi.org/10.1590/S010384782010005000092

MARZEC, A.; LEWICKI, P. P. Antiplasticization of cereal-based products by water. Part I: extruded flat bread. Journal of Food Engineering, v. 73, n. 1, p. 1-8, 2006. http://dx.doi.org/10.1016/j. jfoodeng.2004.12.002

OOMAH, B. D.; MAZZA, G. Compositional changes during commercial processing of flaxseed. Industrial Crops and Products, v. 9, n. 1, p. 29-37, 1998. http://dx.doi.org/10.1016/ S0926-6690(98)00010-7

PÉREZ, A. A. et al. Extrusion cooking of a maize/soybean mixture: factors affecting expanded product characteristics and flour dispersion viscosity. Journal of Food Engineering, v. 87, n. 3, p. 333-340, 2008. http://dx.doi.org/10.1016/j.jfoodeng.2007.12.008
SINGH, N. et al. Physical properties of extruded wheat starch-additive mixture. Cereal Chemistry, v. 75, n. 3, p. 325-330, 1998. http:// dx.doi.org/10.1094/CCHEM.1998.75.3.325

SINGH, B.; SEKHON, K.S.; SING, N. Effects of moisture, temperature and level of pea grits on extrusion behavior and product characteristics of rice. Food Chemistry, v. 100, n. 1, p. 198-202, 2007. http://dx.doi.org/10.1016/j.foodchem.2005.09.042

STANLEY, D. W. Chemical and structural determinants of texture of fabricated foods. Food Technology, v. 40, n. 3, p. 65-68, 76, 1986.

SUKNARK, K.; PHILLIPS, R. D.; CHINNAN, M. S. Physical properties of directly expanded extrudates formulated from partially defatted peanut flour and different types of starch. Food Research International, v. 30, n. 8, p. 575-583, 1997. http://dx.doi. org/10.1016/S0963-9969(98)00016-7

TAVERNA, L. G.; LEONEL, M.; MISCHAN, M. M. Changes in physical properties of extruded sour cassava starch and quinoa flour blend snacks. Ciência e Tecnologia de Alimentos, v. 32 , n. 4 , p. $826-834,2012$. http://dx.doi.org/10.1590/S010120612012005000113

TREVISAN, A. J. B.; ARÊAS, J. A. G. Development of corn and flaxseed snacks with high-fibre content using response surface methodology (RSM). Internation Journal of Food Science and Nutrition, v. 63, n. 3, p. 362-367, 2012. http://dx.doi.org/10.3109/09637486.2011.6 29179

YAGCI, S.; GÖGÜS, F. Response surface methodology for evaluation of physical and functional properties of extruded snack foods developed from food-by-products. Journal of Food Engineering, v. 86, n. 1, p. 122-132, 2008. http://dx.doi.org/10.1016/j.jfoodeng.2007.09.018

YANG, S. H. et al. Effects of adlay species and rice flour ratio on the physicochemical properties and texture characteristic of adlay-based extrudates. Journal of Food Enginering, v. 84, n. 3, p. 489-494, 2008. http://dx.doi.org/10.1016/j.jfoodeng.2007.06.010

YANNIOTIS, S.; PETRAKI, A.; SOUMPASSI, E. Effect of pectin and wheat fibers on quality attributes of extruded cornstarch. Journal of Food Engineering, v. 80, p. 594-599, 2007. http://dx.doi. org/10.1016/j.jfoodeng.2006.06.018

YULIANI, S. et al. Effect of extrusion parameters on flavour retention, functional and physical properties of mixtures of starch and D-limonene encapsulated in milk protein. International Journal of Food Science and Technology, v. 41, n. 2, p. 83-94, 2006. http:// dx.doi.org/10.1111/j.1365-2621.2006.01409.x 